УДК 658.112-022.326:005.332.4

DOI: $10.15673 /$ fie.v12i4.1919

\author{
Дьяченко Ю.В. \\ кандидат економічних наук, доцент \\ кафедра менеджменту та логістики \\ E-mail: ypogarchuk@gmail.com \\ ORCID ID: 0000-0002-8754-3256 \\ Полоус Д.Т. \\ магістрант \\ кафедра менеджменту та логістики \\ Одеська національна академія харчових технологій \\ вул. Канатна, 112, м. Одеса, Україна, 65039 \\ E-mail: dashulia0199@gmail.com \\ ORCID ID: 0000-0002-7768-3239
}

\title{
ШЛЯХИ ПІДВИЩЕННЯ КОНКУРЕНТОСПРОМОЖНОСТІ ВІТЧИЗНЯНИХ ПІДПРИЄМСТВ ТИМЧАСОВОГО РОЗМІЩУВАННЯ В СУЧАСНИХ УМОВАХ ГОСПОДАРЮВАННЯ
}

\begin{abstract}
У статті розглянуто сутність поняття «конкурентоспроможність», «конкурентоспроможність закладів тимчасового розміщування», структуру та динаміку розвитку галузі тимчасового розміщування України, досліджено зв'язок між такими елементами як «конкурентоспроможність» та «конкурентна стратегія». Метою написання статті є дослідження шляхів підвищення конкурентоспроможності вітчизняних підприємств тимчасового розміщування в сучасних умовах господарювання. Предметом дослідження виступає процес підвищення конкурентоспроможності готелів та можливість застосування світового досвіду для вітчизняних підприємств. Результати дослідження представленні у вигляді узагальнення шляхів підвищення конкурентоспроможності, які доцільно використовувати для вітчизняних підприємств тимчасового розміщування.
\end{abstract}

Ключові слова: стратегічне управління, конкурентоспроможність, заклади тимчасового розміщування, конкурентна стратегія, якість готельних послуг.

This work is licensed under a Creative Commons Attribution 4.0 International License http://creativecommons.org/licenses/by/4.0/

Постановка проблеми та її зв'язок з важливими науковими та практичними завданнями. На сьогоднішній день, розвиток сучасної економіки характеризується високою питомою вагою в ній сфери послуг. Діяльність підприємств 3 тимчасового розміщування є одним із важливих елементів сфери послуг, вона виконує функції із забезпечення громадян країни та іноземних гостей житлом, харчуванням, а також різноманітними додатковими послугами.

У ситуації, що склалася на сучасному ринку готельних послуг спостерігається високий рівень конкуренції, ускладнення умов господарювання через економічну кризу, тому все більшої значущості набуває питання управління конкурентоспроможністю. Це зумовлено іiі впливом на всі показники діяльності закладів тимчасового розміщування, особливо на фінансовий результат. Підприємства, що не приділяють уваги управлінню власною конкурентоспроможністю в перспективі недоотримають прибуток та втрачають частку ринку.

Аналіз останніх публікацій по проблемі. Дослідженню поняття «конкурентоспроможність» приділяли увагу М. Портер, Ж.-Ж. Ламбен, I. Ансофф, Ф. Котлер. Дослідженням конкурентоспромо- жності закладів тимчасового розміщування займалися B.І. Охота, Л.В. Бортник, С. Гаврилюк, А. Дурович. Проте, на сьогодні існує потреба в дослідженні світового досвіду підвищення конкурентоспроможності підприємств тимчасового розміщування в сучасних умовах господарювання.

Формулювання цілей дослідження. Метою даної статті є дослідження світового досвіду шляхів підвищення конкурентоспроможності закладів тимчасового розміщування в несприятливих умовах зовнішнього середовища. Завданнями для досягнення поставленої мети є оцінка впливу на конкурентоспроможність іноземних готелей таких складових як: використання емоційного маркетингу, інноваційних технологій та екоінновацій.

Виклад основних результатів та їх обгрунтування. Згідно ДСТУ 4268:2003 «Послуги туристичні. Засоби розміщування», закладами тимчасового розміщування є будь-які об'єкти, які надають гостям і туристам коротко- або довготривалі місця для ночівлі і відпочинку [1].

Відповідно до КВЕД-2010, діяльність підприємств тимчасового розміщування належить до класу I «Тимчасове розміщування й організація харчування», 
що включає у себе два розділи: розділ 55 «Тимчасове розміщування» та розділ 56 «Організація харчування» [2]. Розділ 55 «Тимчасове розміщування» охоплює наступні групи: 55.1 Діяльність готелів і подібних засобів тимчасового розміщування; 55.2 Діяльність засобів розміщування на період відпустки та іншого тимчасового проживання; 55.3 Надання місць кемпінгами та стоянками для житлових автофургонів і причепів; 55.9 Діяльність інших засобів тимчасового ро- зміщування [2]. На основі даних Державної служби статистики були розраховані частки наведених груп в залежності від суми реалізації їх послуг (рис.1) [3].

У 2019 році обсяг реалізованих послуг тимчасового розміщування склав 2420 млн. грн, частка послуг тимчасового розміщування й організації харчування у структурі ВВП становила 0,68\%, а темпи зростання галузі дорівнювали 3\% [3].

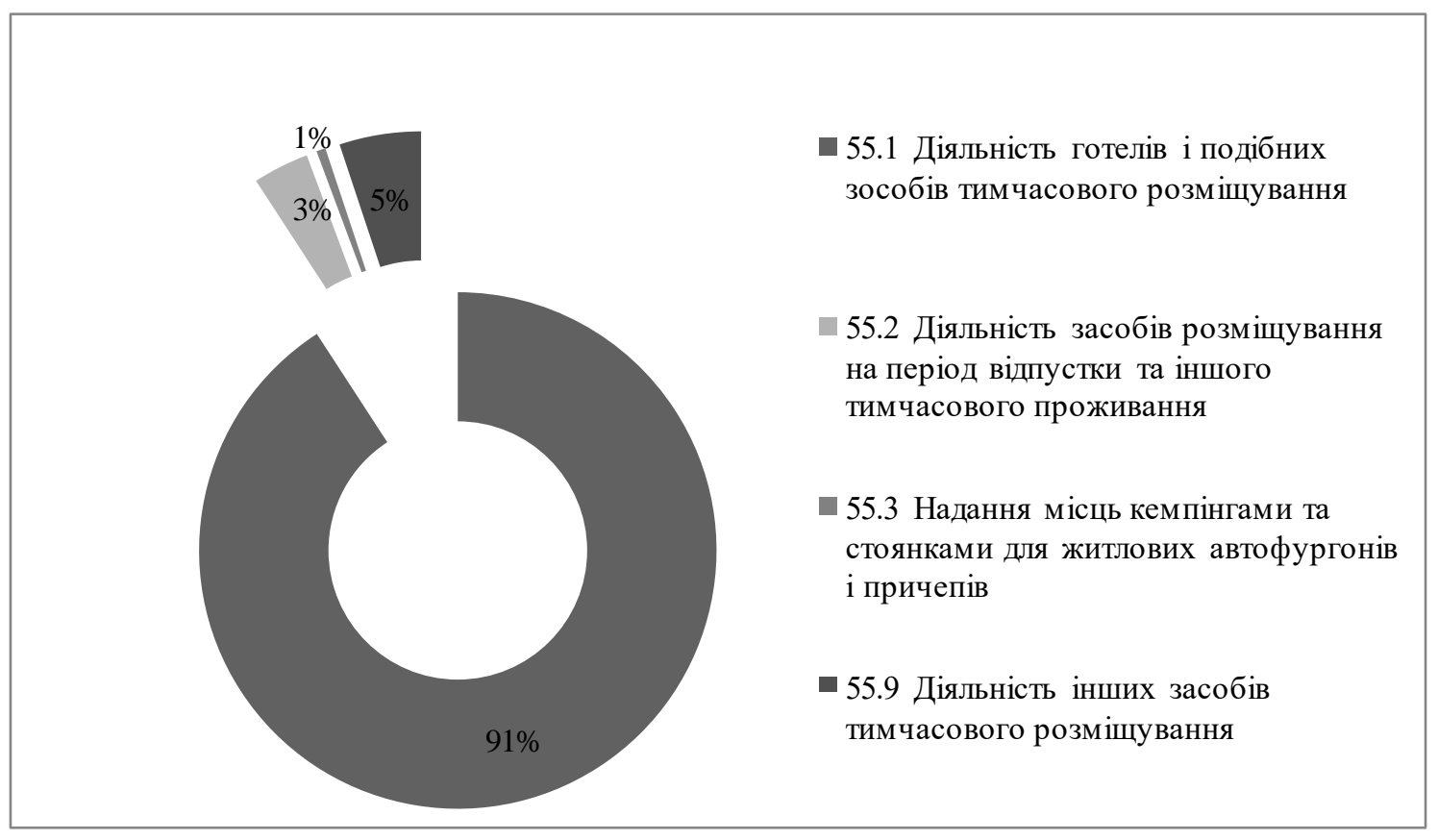

Рис.1. Структура розділу «Тимчасове розміщування»*

*побудовано авторами з використанням джерел [2,3]

Послуги з тимчасового розміщування в Україні надаються нерівномірно, так, найбільший обсяг реалізованих послуг спостерігається в Київській (56\%), Львівській (17\%), Харківській (7\%), Дніпропетровській (6\%) та Одеській (6\%) областях.

Несприятливі умови зовнішнього середовища негативно впливають на діяльність закладів тимчасового розміщування, тому для збільшення економічної ефективності діяльності таким підприємствам необхідно приділяти достатню увагу формуванню та управлінню власною конкурентоспроможністю.

Згідно сучасного економічного словника Райзберга, під конкурентоспроможністю слід розуміти «реальну і потенційну можливість організацій в існуючих умовах проектувати, виготовляти та збувати товари/послуги, які за ціновими і неціновими характеристиками є більш привабливими для споживачів, ніж товари/послуги їх конкурентів» [4]. Л. Бортник наводить наступне визначення конкурентоспроможності закладу тимчасового розміщування - це «така його характеристика, яка $\epsilon$ формою вияву ступеня реалізації його потенційної спроможності формувати, утримувати i використовувати стійкі конкурентні переваги» [5].

Розглядаючи конкурентоспроможність закладу тимчасового розміщування можна виділити набір конкурентних переваг, на які буде спиратися конкурента стратегія. Конкурентна стратегія - це стратегія, яка визначає тип поведінки підприємства у конкурентній боротьбі, визначає конкурентні переваги, за допомогою яких підприємство має змогу найбільш повно та якісно задовольнити потреби споживачів на цільовому ринку. Правильно розроблена та реалізована конкурентна стратегія дозволить підприємству досягти високих конкурентних позицій в галузі та зберегти їх в довгостроковій перспективі. Це досягається безперервним процесом підвищення конкурентоспроможності закладу.

Одним із найважливіших напрямків підвищення конкурентоспроможності в готельному бізнесі $\epsilon$ надання послуг більш високої якості порівняно із конкурентами. Якість послуг підприємства тимчасового розміщування, в сучасних умовах - це найважливіша умова його ефективності, рентабельності та конкурентоспроможності. Кожна складова комплексного обслуговування в готельному закладі являє собою певну послугу (харчування, розміщування, розваги, СПА тощо), надання якої здійснюється за певною технологією. Споживачі оцінюють якість послуг як зіставлення свого очікування з фактичним наданням послуги. Також на оцінку споживача впливає ступінь доступності послуги, репутація підприємства, 
відкритість інформації щодо закладу, надійність, безпека, кваліфікація персоналу, рівень комунікації тощо.

Підвищення якості обслуговування в закладах тимчасового розміщування і підтримання іiі на стабільно високому рівні - це стратегічне завдання управлінця. Не дивлячись на витратність цього процесу, проведення всіх необхідних заходів з підвищення конкурентоспроможності окуповується і веде до зростання прибутку готелю. Окрім високої якості послуг на конкурентоспроможність суттєво впливає і ціновий фактор, тому буде доцільним встановлення клієнтоорієнтованих тарифів, системи знижок тощо [6].

В сучасних умовах господарювання суттєвий вплив на конкурентоспроможність готелю має також ступінь лояльності гостей. Це досягається шляхом створення стійкого емоціонального зв'язку з гостем, що призводить до перетворення фірмового стилю підприємства гостинності в бренд. Бренд забезпечує високу інерційність та тривалий період лояльності споживачів, захищає унікальність закладу від копіювання конкурентами, проте потребує постійних інвестицій в маркетингову діяльність, підвищення якості послуг, поліпшення матеріально-технічної бази тощо.

На думку B.I. Охоти для підвищення конкурентоспроможності вітчизняних готелів доцільно покращити наступні напрями діяльності: фінанси, робота зі споживачами, оптимізація внутрішніх бізнеспроцесів, навчання та розвиток персоналу [7].

Фінанси: стратегічними цілями цього напрямку можуть бути збільшення чистого прибутку готелю; підвищення середньої ціни готельного номера; збільшення кількості споживачів у низький сезон; мінімізація простоїв номерів; розвиток напрямів ресторанного бізнесу та надання додаткових послуг. Показниками цього напрямку можуть стати: відсоток збільшення прибутку; середня ціна готельного номера; відсоток збільшення числа споживачів у низький сезон; кількість постійно зайнятих номерів. Шляхами реалізації фінансового напряму можуть стати: розробка програм заохочення клієнтів, розробка системи гнучких знижок для споживачів під час низьких періодів, маркетингова діяльність [7].

Робота зі споживачами: цілями цього напряму $\epsilon$ розширення спектру запропонованих послуг; підвищення задоволеності; створення нових напрямів залучення клієнтів. Для реалізації потрібно активізувати маркетингову та збутову діяльність, розробляти систему оцінки відгуків споживачів щодо якості обслуговування. Застосування цього типу заходів, призведе до зміни таких показників як кількість нових послуг, кількість позитивних відгуків, кількість нових шляхів залучення клієнтів [7].

Оптимізація внутрішніх бізнес-процесів вимагає виконання таких стратегічних цілей, як зменшення тривалості бронювання номеру клієнтом, поліпшення процесу обслуговування клієнтів, спрощення процесу бронювання номерів через інтернетресурси. Для цього необхідно виконати ряд заходів: автоматизація системи управління, підвищення рівня якості обслуговування клієнтів, створення інформаційної системи оцінки думок споживачів, що призведе до зменшення часу на обслуговування одного клієнта та зменшення скарг клієнтів на обслуговування [7].

Навчання та розвиток персоналу відіграє важливу роль у якості сервісу та послуг, що надаються. Для підвищення кваліфікації персоналу та його задоволеністю умовами праці потрібно складати програму навчання персоналу, проводити анкетування задоволеності персоналу та створювати максимально комфортні умови для розвитку співробітників. Показниками розвитку цього напряму удосконалення конкурентної стратегії $є$ витрати на навчання співробітників (у відсотках) та індекс задоволеності персоналу, що вимірюється у балах від одного до десяти [7].

Також ефективними шляхами підвищення конкурентоспроможності закладів тимчасового розміщування є впровадження інноваційних технологій для розширення додаткових послуг, автоматизація внутрішніх бізнес-процесів. застосування екологічного підходу. Розглянемо досвід іноземних готелів 3 цього питання.

Берлінський готель Swissôtel пропонує послугу під назвою «Deep Sleep». Ця послуга полягає у можливості забронювати кімнату для комфортного сну. Система Deep Sleep була розроблена готелем спільно $з$ медичними фахівцями і дослідником сну Міхаелем Фельдом 3 Кельну для постояльців, які страждають від стресів і проблем зі сном [8].

Нововведенням готельної групи InterContinental $є$ номер, в якому гості зможуть впоратися 3 хропінням партнера. Номер обладнаний звукоізоляцією гостям надаються спеціальні підкладки під спину, створені для того, щоб людина, що їх використовує спала на спині, і подушки проти хропіння. Крім того, в номері встановлена машина білого шуму, що усуває звуки хропіння [8].

Готель Palace Hotel di Milano Marittima запустив новий унікальний сервіс - готель дарує пару черевиків, індивідуально виготовлену для клієнта. Взуття виготовлюється 3 натуральної шкіри, пофарбованої барвником рослинного походження [9].

Готелі Park Hyatt пропонують комфортні умови перебування в готелі для мандрівників із дітьми. Пакет послуг VIB - Very Important Baby передбачає розміщування в номері 3 дитячим ліжечком іншими додатковими зручностями, великим вибором іграшок. В ресторанах готелів спеціально розроблене дитяче меню. Послуга VIB доступна для дітей у віці до трьох років та входить у вартість проживання.[10].

Royal Grand Sharm впливає на споживача шляхом подарунку клієнтам пальмового дерева. Воно залишається на території готельного комплексу, але на ньому з'являється табличка з ім'ям постійного гостя, а тайські готелі дарують молодятам, які проводять весілля безпосередньо на їх території «Дерево любові». Висаджування дерева є частиною весільної церемонії і вважається символом початку нового щасливого життя [11].

Сьогодні велика кількість закладів тимчасо- 
вого розміщування по всьому світу використовують технології аромамаркетингу в дезодоруванні приміщень, серед них - Marriott, Travel Charme Hotels, Holiday Inn, Arverna Kongress Hotel, Hotel Dreiklang, Hotel Mercure. Аромамаркетинг - це комплекс заходів щодо використання впливу запахів на поведінку людини і стимулювання іiі потреб в товарах і послугах, створення позитивного сприйняття готелю та підвищення лояльності [12].

Трендом сьогодення $є$ використання екологічних інновацій в готельній індустрії. Це реалізується в будівництві з екологічно чистих природних матеріалів, використанні поновлюваних джерел енергії та призводить до зниження споживання ресурсів. Застосування екологічних розробок експерти вважають вигідним, бо екоінновації надають готелям конкурентних переваг. Не всі вітчизняні готелі можуть дозволити собі впровадження останніх технологій, але всі, незалежно від давності їх введення в експлуатацію, можуть знайти можливості використовувати екологічні інновації - найважливіше виявити, що справді потрібно гостю і що дозволить не тільки зберегти енергію і ресурси, але і створити позитивний імідж готелю, тобто підвищити його конкурентоспроможність.

Висновки та перспективи подальших досліджень. Таким чином, для підвищення конкурентоспроможності іноземні готелі намагаються встановити більш довготривалий контакт зі споживачем, використовуючи інструменти емоційного маркетингу. Вони якісно досліджують ринок та готові оперативно реа- гувати на зміни попиту, пропонуючи якісне задоволення потреб споживача.

В сучасних умовах господарювання вітчизняні заклади тимчасового розміщування можуть використовувати світовий досвід і підвищувати власну конкурентоспроможність використовуючи наступні шляхи:

- відслідковувати зміни у потребах споживачів та швидко на них реагувати;

- встановлювати 3 гостем стійкий емоційний зв'язок, що спонукатиме його виявляти постійну зацікавленість закладом: людина схильна концентрувати більше уваги на речах, здатних викликати емоції, тому важливо впливати на всі почуття людини: звук, вигляд, запах, тактильні відчуття і смак.

- розробляти різноманітні програми лояльності;

- застосовувати сучасні технології, що значно покращить рівень сервісу та розвантажить співробітників, які зможуть більш повно та якісно обслуговувати клієнтів в цей час;

- раціонально використовувати ресурси та застосовувати екоінновації.

Отже поставлена мета дослідження, що полягала у вивчені світового досвіду шляхів підвищення конкурентоспроможності закладів тимчасового розміщування в несприятливих умовах зовнішнього середовища була досягнута, завдання виконані. Перспективою для подальших досліджень є питання управління конкурентоспроможністю підприємств тимчасового розміщування в умовах жорсткого карантину, спричиненого коронавірусом SARS-CoV-2.

\section{Література}

1. ДСТУ 4268:2003 . Послуги туристичні. Засоби розміщування: чинний від 01.07.2004. Київ. С. 48.

2. Класифікація видів економічної діяльності (КВЕД-2010): [Веб-сайт]. Київ, 2020. URL: http://kved.ukrstat.gov.ua/KVED2010/kv10_i.html (дата звернення: 15.10.2020).

3. Сайт Державної служби статистики України: [Веб-сайт]. Київ, 2020. URL: http://www.ukrstat.gov.ua (дата звернення: 10.10 .2020$)$. 2008. $480 \mathrm{c}$

4. Райзберг Б. А. Словарь современных экономических терминов: словник. Москва: Айрис-пресс,

5. Бортник Л. В. Комплексна оцінка конкурентоспроможності підприємств готельного бізнесу // Видавничополіграфічний центр Тернопільського національного економічного університету “Економічна думка": зб. наук. пр. Тернпіль, 2013.Том 14.№ 2. С.100-110.

6. Пандяк I. Конкурентоспроможність готельних підприємств: ресурси, ризики, стратегія управління // Вісник Львівського університету. Сер. Географічна. 2018. № 52. С. 222-231.

7. Охота В. Шляхи підвищення конкурентоспроможності підприємств готельної індустрії // Економічна наука. 2007. вип. 1, № 5. С. 46-49.

8. Отельная фишка: Глубокий сон // Портал для профессионалов гостиничного и ресторанного бизнеca: [Веб-сайт]. URL: http://prohotelia.com.ua/2012/03/deep-sleep (дата звернення: 12.06.2020).

9. Отельная фишка «Антихраповый номер» // Портал для профессионалов гостиничного и ресторанного бизнеса: [Веб-сайт]. URL: http://prohotelia.com/2011/09/anti-snoring-crowne-plaza (дата звернення: 15.07.2020).

10. Отельная фишка: Обувь от дизайнера в подарок // Портал для профессионалов гостиничного и ресторанного бизнеса: [Веб-сайт]. URL: http://prohotelia.com/2011/06/отельная-фишка-обувь-от-дизайнера-в-по (дата звернення: 13.06 .2020$)$.

11. Отельная фишка: VIB - Very Important Baby // Портал для профессионалов гостиничного и ресторанного бизнеса: [Веб-сайт]. URL: http://prohotelia.com/2011/04/very-important-baby (дата звернення: 12.06.2020). 
12. Отельная фишка: Дерево в подарок // Портал для профессионалов гостиничного и ресторанного бизнеса: [Веб-сайт]. URL: http://prohotelia.com.ua/2011/04/tree-like-a-gift (дата звернення: 12.06.2020).

13. Пуцко Д. В. Аромомаркетинг // Економічні проблеми сталого розвитку: матеріали наук.-тех. конф. студентів, аспірантів і молодих учених, присвяченої 80-річчю О. Балацького, Суми, 21-25 квіт. 2017 р. / Сум. дер. університет. Суми, 2017. С. 302-303.

14. Робертс К. Lovemarks. Бренды будущого. М.: Рипол Классик, 2005. 224 с.

15. Балацька Н. Ю. Імідж як фактор конкурентоспроможності готельного підприємства // Молодий вчений. 2016. № 11. С. 551-554.

Стаття надійшла 15.10.2020

Стаття прийнята до друку 29.10.2020

Доступно в мережі Internet 29.12.2020

\author{
Дьяченко Ю.В. \\ кандидат экономических наук, доцент \\ кафедра менеджмента и логистики \\ E-mail: ypogarchuk@gmail.com \\ ORCID ID: 0000-0002-8754-3256 \\ Полоус Д.Т. \\ магистрант \\ кафедра менеджмента и логистики \\ Одесская национальная академия пищевых технологий \\ ул. Канатная, 112, г. Одесса, Украина, 65039 \\ E-mail: dashulia0199@gmail.com \\ ORCID ID: 0000-0002-7768-3239
}

\title{
ПУТИ ПОВЫШЕНИЯ КОНКУРЕНТОСПОСОБНОСТИ ОТЕЧЕСТВЕННЫХ ПРЕДПРИЯТИЙ ВРЕМЕННОГО РАЗМЕЩЕНИЯ В СОВРЕМЕННЫХ УСЛОВИЯХ ХОЗЯЙСТВОВАНИЯ
}

В статье рассмотрено понятие конкурентоспособности заведений временного размещения, структура и динамика развития отрасли временного размещения Украине, исследована связь между такими элементами как «конкурентоспособность» и «конкурентная стратегия». Конкурентоспособность предприятия временного размещения - это «такая его характеристика, которая является формой проявления степени реализации его потенциальной способности формировать, удерживать и использовать устойчивые конкурентные преимущества». Целью написания статьи является исследование путей повышения конкурентоспособности отечественных предприятий временного размещения в современных условиях хозяйствования. Предметом исследования выступает процесс повышения конкурентоспособности гостиниц и возможность применения мирового опыта для отечественных предприятий. Основными заданиями исследования является оценка влияния на конкурентоспособность заведений временного размещения таких факторов как: использование эмоционального маркетинга, инновационных технологий и экоинноваций. В результате проведения исследования было выявлено, что иностранные гостиницы пытаются установить более долговременный контакт с потребителем, используя инструменты эмоционального маркетинга, они качественно исследуют рынок и готовы оперативно реагировать на изменения спроса, предлагая качественное удовлетворение потребностей гостей. Таким образом, отечественные предприятия, предоставляющие услуги временного размещения могут использовать мировой опыт улучшения конкурентоспособности, используя следующие пути: отслеживать изменения в потребностях потребителей, быть гибким в плане оказываемых услуг; человек предрасположен концентрировать больше внимания на вещах, способных вызвать эмоции, поэтому важно воздействовать на все чувства человека: звук, вид, запах, тактильные ощущения и вкус. Нужно устанавливать с клиентом устойчивую эмоциональную связь, побуждать его проявлять постоянную заинтересованность, использовать различные программы лояльности, применять в деятельности заведений временного размещения современные технологии, рационально использовать ресурсы и применять энергосберегающие технологии.

Ключевые слова: стратегическое управление, конкурентоспособность, заведения временного размещения, конкурентная стратегия, качество отельных услуг. 


\author{
Diachenko Yu. \\ Ph.D., Associate Professor \\ Department of Management and Logistics \\ E-mail: ypogarchuk@gmail.com \\ ORCID ID: 0000-0002-8754-3256 \\ Polous D. \\ Undergraduate \\ Department of Management and Logistics \\ Odessa National Academy of Food Technologies \\ Kanatna str., 112, Odesa, Ukraine, 65039 \\ E-mail: dashulia0199@gmail.com \\ ORCID ID: 0000-0002-7768-3239
}

\title{
THE WAYS TO INCREASE THE COMPETITIVENESS OF DOMESTIC ENTERPRISES OF TEMPORARY PLACEMENT IN MODERN ECONOMIC CONDITIONS
}

The article discusses the concept of competitiveness of temporary accommodation establishments, the structure and dynamics of development of the industry of temporary accommodation in Ukraine, investigates the relationship between such elements as "competitiveness" and "competitive strategy". The competitiveness of a temporary accommodation enterprise is "such a characteristic that is a form of manifestation of the degree of realization of its potential ability to form, maintain and use sustainable competitive advantages." The purpose of the article is to study the ways to improve the competitiveness of domestic enterprises of temporary placement in modern economic conditions. The subject of the research is the process of increasing the competitiveness of hotels and the possibility of applying world experience for domestic enterprises. The main tasks of the study are to assess the impact on the competitiveness of temporary accommodation establishments of such factors as: the use of emotional marketing, innovative technologies and ecoinnovations. As a result of the study, it was revealed that foreign hotels are trying to establish a more longterm contact with the consumer using emotional marketing tools, they qualitatively research the market and are ready to quickly respond to changes in demand, offering high-quality satisfaction of guests' needs. Thus, domestic enterprises providing temporary accommodation services can use the global experience of improving competitiveness using the following ways: track changes in consumer needs, be flexible in terms of services provided; a person is predisposed to concentrate more attention on things that can cause emotions, therefore it is important to influence all human senses: sound, sight, smell, tactile sensations and taste. It is necessary to establish a stable emotional connection with the client, encourage him to show constant interest, use various loyalty programs, apply modern technologies in the activities of temporary accommodation establishments, rationally use resources and apply energy-saving technologies.

Key words: strategic management, competitiveness, enterprises of temporary placement, competitive strategy, the quality of hotel services.

\section{References}

1. DSTU 4268:2003 . Posluhy turystychni. Zasoby rozmishchuvannia. Chynnyi vid 01.07.2004. (2004). Kyiv.

2. Klasyfikatsiia vydiv ekonomichnoi diialnosti (KVED-2010). (2020). Retrieved October 15, 2020, from http://kved.ukrstat.gov.ua/KVED2010/kv10_i.html

3. Sait Derzhavnoi sluzhby statystyky Ukrainy. (2020). Retrieved October 10, 2020, from http://www.ukrstat.gov.ua

4. Rayzberg, B. A. (2008). Slovar sovremennyih ekonomicheskih terminov: slovnik. Moscow: Ayris-press.

5. Bortnyk, L. V. (2013). Kompleksna otsinka konkurentospromozhnosti pidpryiemstv hotelnoho biznesu. Vydavnychopolihrafichnyi tsentr Ternopilskoho natsionalnoho ekonomichnoho universytetu "Ekonomichna dumka", 14(2), 100-110.

6. Pandiak, I. (2018). Konkurentospromozhnist hotelnykh pidpryiemstv: resursy, ryzyky, stratehiia upravlinnia. Visnyk Lvivskoho universytetu, (52), 222-231.

7. Okhota, V. (2007). Shliakhy pidvyshchennia konkurentospromozhnosti pidpryiemstv hotelnoi industrii. Ekonomichna nauka, 1(5), 46-49.

8. Otelnaya fishka: Glubokiy son. Portal dlya professionalov gostinichnogo i restorannogo biznesa. Retrieved June 12, 2020, from http://prohotelia.com.ua/2012/03/deep-sleep 
9. Otelnaya fishka «Antihrapovyiy nomer». Portal dlya professionalov gostinichnogo i restorannogo biznesa. Retrieved July 15, 2020, from http://prohotelia.com/2011/09/anti-snoring-crowne-plaza

10. Otelnaya fishka: Obuv ot dizaynera v podarok. Portal dlya professionalov gostinichnogo i restorannogo biznesa. Retrieved June 13, 2020, from http://prohotelia.com/2011/06/otelnaya-fishka-obuv-ot-dizaynera-v-po

11. Otelnaya fishka: VIB - Very Important Baby. Portal dlya professionalov gostinichnogo i restorannogo biznesa. Retrieved June 12, 2020, from http://prohotelia.com/2011/04/very-important-baby

12. Otelnaya fishka: Derevo v podarok. Portal dlya professionalov gostinichnogo i restorannogo biznesa. Retrieved June 12, 2020, from http://prohotelia.com.ua/2011/04/tree-like-a-gift

13. Putsko, D. V. (2017). Aromomarketynh (thesis). Ekonomichni problemy staloho rozvytkumaterialy nauk, Sumy, 302-303.

14. Roberts, K. (2005). Lovemarks. Brendyi buduschogo. Moscow: Ripol Klassik.

15. Balatska, N. Yu. (2016). Imidzh yak faktor konkurentospromozhnosti hotelnoho pidpryiemstva. Molodyi vchenyi, (11), 551-554.

Received 15 October 2019

Approved 29 October 2019

Available in Internet 29.12.2020

Цитування згідно ДСТУ 8302:2015

Дьяченко Ю.В., Полоус Д.Т. Шляхи підвищення конкурентоспроможності вітчизняних підприємств тимчасового розміщування в сучасних умовах господарювання // Економіка харчової промисловості. 2020. Т.12, вип. 4. С. 98-104. doi: 10.15673/fie.v12i4.1919

Cite as APA style citation

Diachenko, Yu., \& Polous, D. (2020). The ways to improve the competitiveness of domestic enterprises of temporary placement in modern economic conditions. Food Industry Economics, 12(4), 98-104. doi: 10.15673/fie.v12i4.1919 